DOI 10.14746/ps.2014.1.8

Uniwersytet im. Adama Mickiewicza w Poznaniu

\title{
OBWÓD KALININGRADZKI A BEZPIECZEŃSTWO POLSKI
}

Na długości 231,9 km rozciaga się granica pomiędzy Polską a Obwodem Kaliningradzkim (dalej: OK). Enklawa ta, licząca 15,1 tys. km² (wielkość Luxemburga, stanowiąca zaledwie 0,088\% powierzchni największego kraju świata), którą zamieszkuje 955 tys. mieszkańców (2013 r.), stanowi najbardziej na zachód wysunięty obszar Federacji Rosyjskiej (FR).

Z punktu widzenia bezpieczeństwa Polski region ten odgrywał i odgrywa nadal istotne znaczenie. W okresie międzywojennym Prusy Wschodnie, na obszarze których usytuowany jest OK, stanowiły istotne zagrożenie militarne dla Polski. Oskrzydlały one od północy Polskę (tzw. „wschodniopruski gruszkowaty nawis”). Dla Rzeszy, ta najbardziej na północ wysunięta prowincja posiadała ważne znaczenie wojskowe, m.in. stwarzała możliwość szachowania państw bałtyckich oraz umożliwiała nawiązywanie kontaktów wojskowych z Rosją. Prusy Wschodnie odegrały ważną rolę militarną w agresji na Polskę 1 września 1939 r. oraz na ZSRR 21 czerwca 1941 r. Samoloty Luftwaffe startujące m.in. z lotnisk w Królewcu, Bartoszycach, Wystruci i Elblagu, pokonując zaledwie $110 \mathrm{~km}$ od granicy, dokonywały pierwszych w II wojnie światowej nalotów terrorystycznych na Warszawę. Oddziały 3 Armii Wehrmachtu stacjonujące w Prusach Wschodnich uderzyły „najkrótszą drogą” na Warszawę, Toruń oraz Włocławek. Podobną rolę odegrały oddziały Wehrmachtu i Luftwaffe w 1941 r., biorąc z powodzeniem udział w ataku na ZSRR (Wróblewski, 1998: 268-316).

Pokonanie Polski w 1939 r. oznaczało likwidację ,,haniebnego korytarza” i ,wyspowego charakteru" (Insellage) oraz połączenie prowincji z resztą III Rzeszy. Polskie władze na uchodźstwie od początku były przekonane o konieczności likwidacji Prus Wschodnich, głównie ze względu na przyszłe bezpieczeństwo państwa. Zakładano ich inkorporację do Rzeczpospolitej. Planowano, iż północna część prowincji ( $M a-$ melland, Kraj Kłajpedzki) wejdzie w skład Litwy, co w przyszłości ułatwić miało współpracę polsko-litewską, likwidując spór o Wilno. Nie zakładano natomiast przyłączenia części tego obszaru do ZSRR, obawiając się w przyszłości odrodzenia się współpracy niemiecko-radzieckiej, co oceniono jako szczególnie niebezpieczne dla polskiej racji stanu zarówno ówcześnie, jak i w przyszłości. Podobne stanowisko zajmowali polscy komuniści skupieni wokół PKWN, KRN i rządu lubelskiego (Wrzesiński, 1994: 336-432).

Litewskie władze na emigracji były przekonane, że większość obszaru Prus Wschodnich, łącznie z Królewcem, winno wejść w skład odrodzonego demokratycznego państwa litewskiego. Polakom należały się jedynie południowe ,polskie powiaty" Prus Wschodnich". Nowy zasięg terytorialny Republiki Litewskiej (łącznie 
z Wileńszczyzną i Suwalszczyzną) winien przebiegać w Prusach Wschodnich wzdłuż dziewiętnastowiecznej „litewsko-polskiej granicy językowej” na linii: Gołdap-Szczytno-Olsztyn (Sakson, 2012: 153-170; Sakson, 2011a: 170-174).

Upadek Prus Wschodnich był konsekwencją II wojny światowej, a w szczególności zajęciem tego obszaru przez Armię Czerwoną. Zgodnie z wolą J. Stalina dokonano podziału i likwidacji Prus Wschodnich. Północne obszary prowincji wraz z Królewcem weszły w skład ZSRR (Kraj Kłajpedzki przyłączony został do Litewskiej SRR a region Królewca, późniejszy Obwód Kaliningradzki, wszedł w skład Rosyjskiej FSRR). Południowe obszary Prus Wschodnich (Warmia i Mazury) przyłączone zostały do Polski. Stalin oficjalnie argumentował fakt podziału Prus Wschodnich koniecznością uzyskania przez zwycięskie ZSRR ,satysfakcji terytorialnej” w postaci „kawałka niemieckiej ziemi”, konieczności posiadania niezamarzających portów nad Bałtykiem w Królewcu i Kłajpedzie oraz udzielenia Polsce rekompensaty terytorialnej za utratę Kresów Wschodnich.

Rzeczywistym powodem podziału Prus Wschodnich były jednak względy geopolityczne i strategiczne. Stalin dążył do utrzymania „w kleszczach” Litwy, Łotwy i Estonii, okrążenia Polski, której dalsze losy nie były podówczas jeszcze rozstrzygnięte oraz maksymalnego oddzielenia Litwy od Polski. Oznaczało to ugruntowanie dominującej roli ZSRR, w tej części Europy m.in. poprzez wywieranie presji na sąsiadów od strony zmilitaryzowanej części imperium oraz stworzenie dogodnego zaplecza dla potencjalnego konfliktu zbrojnego z Zachodem. Ostateczne rozstrzygnięcie w sprawie Prus Wschodnich, sankcjonujące plany Stalina, zapadło na konferencji w Poczdamie w 1945 r. (Teheran-Jalta-Poczdam, 1972: 86-87, 169, 476).

W okresie powojennym, szczególnie po całkowitym wysiedleniu ludności niemieckiej w latach 1947-1949, Obwód Kaliningradzki stał się zamknięta, zmilitaryzowaną strefą wojskowa, niedostępną nie tylko dla cudzoziemców, ale także dla obywateli ZSRR (Sakson, 2011b: 161-181, 191-194).

W radzieckich planach strategicznych z lat 1945-1960 wojska stacjonujące w obwodzie (około 100-200 tys.) miały do spełnienia głównie zadanie defensywne, stanowiąc zaplecze dla jednostek pierwszorzutowych stacjonujących w Niemczech Wschodnich. W okresie późniejszym, do rozpadu ZSRR w 1991 r., przeformułowano zadania dla sił zbrojnych stacjonujących w tym rejonie na bardziej ofensywne. Dowództwo Floty Bałtyckiej, znajdujące się w Bałtyjsku i Kaliningradzie, przygotowywało plany przeprowadzenia wspólnie m.in. z oddziałami piechoty morskiej Wojska Polskiego, desantów na cieśniny duńskie (Szymański, 1999: 137-154; Chełminiak, 2009: 76-79).

Upadek systemu komunistycznego oraz rozpad ZSRR wywołał szereg następstw, które posiadały istotne znaczenie nie tylko dla mieszkańców regionu, władz centralnych w Moskwie, ale także dla bezpieczeństwa Polski i Europy. W latach 1991-1999, tj. w okresie rządów Borysa Jelcyna, nazywanych przez Rosjan „okresem wielkiej smuty” lub ,przeklętymi latami dziewięćdziesiątymi”, wystąpiło wiele zjawisk i procesów, które wywarły istotny wpływ na bezpieczeństwo Rzeczpospolitej.

Rozpad ZSRR oraz odzyskanie niepodległości przez państwa bałtyckie spowodował zasadniczą zmianę położenia geopolitycznego Obwodu Kaliningradzkiego. Podobnie jak międzywojenne Prusy Wschodnie, obwód został „oddzielony” od macierzy. Stał się enklawą, „wyspą” otoczoną przez państwa (Polska i Litwa), które stały się 
członkami „wrogiego” NATO i Unii Europejskiej. W praktyce oznacza to, iż obwód może być potencjalnym polem napięć i konfliktów pomiędzy Rosją a NATO i UE. Fakt ten posiada istotny wpływ na bezpieczeństwo Polski.

Współczesne położenie Obwodu Kaliningradzkiego pod względem geopolitycznym i ekonomicznym jest wyjątkowe. Mieszkańcy obwodu, by dotrzeć do centralnej Rosji muszą przejechać przez terytorium Litwy oraz Białorusi (Kaliningrad-Wilno-Mińsk-Smoleńsk) lub Łotwy (Kaliningrad-Litwa-Ryga-Psków). Istotnym zagrożeniem dla interesów Polski były plany władz w Moskwie, z lat 1993-1994 oraz z 2001 r. dotyczące budowy specjalnego „korytarza drogowego”, który omijając Litwę miał przebiegać przez północny obszar Polski i połączyć obwód z Białorusią. W Obwodzie Kaliningradzkim przystąpiono do budowy stosownego „łącznika” drogi na planowanej trasie: Gusiew-Gołdap-Suwałki-Grodno. Strona polska ze zrozumiałych względów odrzuciła plany budowy „korytarza suwalskiego” i wprowadzenia jakiegokolwiek specjalnego trybu tranzytu. Analogia z planami Adolfa Hitlera, budowy „eksterytorialnej autostrady" przez Korytarz Pomorski, która połączyć miała Prusy Wschodnie z obszarem III Rzeszy i stała się jednym z pretekstów do wybuchu II wojny światowej ${ }^{1}$, była dla Polaków zbyt czytelna i z góry wykluczająca rosyjskie plany.

Obwód Kaliningradzki dzieli odległość 600 km od „właściwej Rosji”. Od Kaliningradu liczącego 435 tys. mieszkańców (prawie połowa osób żyjących w obwodzie), stolicy regionu, do granicy z Polską jest zaledwie $35 \mathrm{~km}$, a do granicy z Litwą $70 \mathrm{~km}$. Do Moskwy odległość ta wynosi aż $1300 \mathrm{~km}$, podczas gdy do Warszawy około $300 \mathrm{~km}$, a do Berlina ponad $600 \mathrm{~km}$.

Dekompozycja dwubiegunowego układu sił na świecie wymusiła potrzebę opracowania przez Rosję i Polskę nowej strategii bezpieczeństwa i obrony. Rola Obwodu Kaliningradzkiego w nowym układzie sił nie uległa zasadniczej zmianie. Stanowił on nadal najbardziej wysunięty na zachód „posterunek zbrojny” Rosji. Nabrał on nowego znaczenia po wycofaniu się wojsk Federacji Rosyjskiej z terytorium Niemiec oraz Polski. Część tych wojsk została skierowana do obwodu, co spowodowało zaniepokojenie w Polsce i państwach bałtyckich.

W okresie rządów B. Jelcyna nastapiła istotna redukcja liczby wojsk stacjonujących w obwodzie. Głęboki kryzys gospodarczy panujący w ówczesnej Rosji w sposób szczególny dotknął mieszkańców obwodu. Uzależniona od centralnych dotacji i zewnętrznych dostaw, gospodarka regionu znalazła się na krawędzi upadku. Efektem „nowego otwarcia" była także utrata statusu zamkniętej strefy wojskowej. Przejawem zachodzących zmian było m.in. stworzenie Specjalnej Strefy Ekonomicznej, która przyciagnąć miała zagraniczny kapitał inwestycyjny. Toczono podówczas ożywione dyskusje na temat przyszłości obwodu. Rozważano bardziej lub mniej realistyczne koncepcje: od stworzenia autonomicznego regionu w strukturach FR, poprzez przekształcenie enklawy w kolejne państwo nadbałtyckie (obok Litwy, Łotwy, Estonii), czy też powstanie kondominium pod auspicjami Unii Europejskiej, a na utopijnych kon-

1 W 1938 r. oddano do użytku 92 kilometrowy odcinek, ,jednojezdniowej autostrady" (Reichsautobahn - RAB 3) łączącej Królewiec z Elblagiem, który prowadzić miał do granicy z Polską. Stanowił on część wielkiego projektu autostradowego, mającego połączyć Prusy Wschodnie z Rzeszą na trasie: Królewiec-Elbląg-Szczecin-Berlin (tzw. berlinka). Patrz: Schütz, Gruber (2000). 
cepcjach kończąc (przekazanie obwodu Polsce, Litwie lub Niemcom) (Sakson, 1993; Sakson, 1994c; Sakson, 1994b: 101-114). Stanowisko władz Rosji w tej sprawie było stałe i niezmienne. Ze względu na rację stanu oraz z uwagi na sprawy bezpieczeństwa państwa, Obwód Kaliningradzki był, jest i pozostanie „niezatapialnym lotniskowcem” na zachodnich rubieżach Rosji. Tak jak Wielka Brytania nie miała i nie ma zamiaru przekazać Hiszpanii bazy militarnej w Gibraltarze, strzegącej wpływów Zjednoczonego Królestwa w tej części świata, tak politycy na Kremlu nie dopuszczają myśli o zmianie statusu obwodu będącego symbolem ,zachodniego bastionu” państwa (,sama zapadnaja").

Kierując się racją stanu oraz względami bezpieczeństwa państwa, władze i poważne siły polityczne w Polsce nie były i nie są zainteresowane kwestionowaniem status quo, w tym szczególnie podważenia przynależności obwodu do Rosji. W przeciwnym razie oznaczałoby to powrót do dyskusji nad kształtem terytorialnym i przebiegiem granic, w tym szczególnie międzynarodowo-prawnym statusem Ziem Zachodnich i Północnych Polski, czyli byłych wschodnich obszarów Niemiec przyłączonych w 1945 r. do Polski. Inaczej do tej kwestii podchodzili politycy w Wilnie. W interesie Polski leży, iżby Obwód Kaliningradzki był regionem przewidywalnym, o stabilnej sytuacji społeczno-gospodarczej, który nie stanowiłby zagrożenia dla bezpieczeństwa państwa (Sakson 1994a; Sakson, 1994d: 101-114).

Przejęcie władzy w Rosji w 2000 r. przez Władimira Putina zapoczątkowało nowy okres w najnowszych dziejach Rosji. Wywarło ono istotny wpływ na sytuację w Obwodzie Kaliningradzkim oraz na relacje polsko-rosyjskie.

Konsolidacja władzy, powstanie „państwa Putina” polegającego w sensie politycznym na stworzeniu systemu biurokratyczno-oligarchiczno-autorytarnego, a w sensie ekonomicznym na peryferyjnym kapitalizmie biurokratycznym, stabilizacja i rozwój gospodarczy w latach 2001-2008 przekładający się na odczuwalny wzrost poziomu życia (po rozpadzie ZSRR stopa życiowa gwałtownie się obniżyła - niemal o połowę) (Politkowska, 2005; Politkowska, 2007), to główne czynniki wpływające na sytuację w Obwodzie Kaliningradzkim. Na relacje polsko-rosyjskie, w tym miejsce obwodu w polskiej polityce bezpieczeństwa, istotne znaczenie odgrywa dążność władz na Kremlu do odbudowania mocarstwowości Rosji. Przejawem tej polityki jest m.in. reintegracja dawnej strefy wpływów (unia celna z Białorusią i Kazachstanem, ,ponowne odzyskanie" Ukrainy itp.) (Winiecki, 2012: 48-50).

W grudniu 2013 r. do opinii publicznej w Niemczech i w Polsce dotarly alarmujące informacje o rozmieszczeniu rakiet Iskander $M$ w Obwodzie Kaliningradzkim. Mgliste reakcje strony rosyjskiej na informacje o rakietach w Kaliningradzie miały jeden cel - przestraszyć społeczeństwa Niemiec i Polski, by wymusiły na politykach porzucenie planów budowy w Polsce amerykańskiej tarczy antyrakietowej i natowskiego systemu obrony przeciwrakietowej. Podobne informacje o rakietach Iskander pojawiły się w styczniu 2012 r. $^{2}$ oraz w 2009 r. (Radziwinowicz, 2009: 8). Również wcześniej Rosjanie straszyli polską i europejską opinię publiczną groźbą instalacji rakiet bali-

2 Jako pierwszy o zainstalowaniu rakiet Iskander w Obwodzie Kaliningradzkim doniósł niemiecki tabloid „Bild” (patrz: http://www.bild.de, 14.12.2013). Przejęły to polskie media. 
stycznych z głowicami jądrowymi na terytorium Obwodu Kaliningradzkiego (Jendroszczyk, 1998: 9).

Dlaczego systematycznie pojawiają się tego rodzaju informacje? Aby wyjaśnić tę kwestię należy sięgnąć do ogólnych założeń współczesnej rosyjskiej polityki globalnej w tym wobec NATO i UE.

Zdaniem Siergieja Briukowa i Władysława Sawina autorów opracowania z 2013 r. pod znamiennym tytułem Rosja - renesans potęgi?, aktualnie Federacja Rosyjska znajduje się w „fazie przejściowej w kierunku geopolitycznej wielkiej przestrzeni”. Gdyby Rosji nie udało się na nowo zdefiniować i stworzyć skonsolidowanego narodowego państwa Rosji-Euroazji w wielobiegunowym świecie, wówczas należy się liczyć z powstaniem na tym obszarze ,geopolitycznej «próżni»”, którą wypełni „etniczny nacjonalizm, radykalny islam i transnarodowa zorganizowana przestępczość" (Briukow, Sawin, 2013: 139). Innymi słowy, przed Rosją stoi zadanie odbudowy mocarstwa.

Podstawą ,euroazjatyckiej wielkiej przestrzeni” będzie unia celna Rosji, Białorusi i Kazachstanu, która została przez te państwa zadeklarowana 18 listopada 2011 r. w postaci Unii Euroazjatyckiej. Istota ,projektu przyszłej euroazjatyckiej wielkiej przestrzeni" jest stworzenie geopolitycznej i geoekonomicznej jedności. Projekt Unii Euroazjatyckiej stworzy możliwość modernizacji państw postsowieckich oraz ich powrót do wielkiej polityki światowej w roli globalnego aktora, bez utraty własnej suwerenności. Celem Unii, która powstanie na bazie dobrowolności jest polityczna, ekonomiczna, militarna i kulturalna konsolidacja państw członkowskich. Stanowić będzie ona adekwatną odpowiedź na wyzwania współczesnego świata (ibidem: 139-141). Projekt Unii Euroazjatyckiej stanowi priorytetowe zadanie dla rosyjskiej polityki zagranicznej. Zdaniem S. Briukowa i W. Sawina przyszłymi partnerami dla Unii Euroazjatyckiej będzie Unia Europejska, w tym szczególnie Niemcy oraz w ograniczonym zakresie Francja. Na obszarze Azji Wschodniej rolę taką pełnić będzie ChRL, która postrzegana jest w Rosji jako „nowa siła przywódcza polityki światowej”. Unia Euroazjatycka winna pełnić rolę pomostu pomiędzy tymi regionami.

Strategicznymi partnerami Rosji są Brazylia i Indie. Oba te państwa w ramach organizacji BRICS dążą w sposób pokojowy do skupienia wokół siebie państw sąsiednich. $\mathrm{W}$ tak zarysowanej wizji nowego ładu międzynarodowego, Stany Zjednoczone postrzegane są z perspektywy Unii Euroazjatyckiej jako siła reprezentująca „naturalne” interesy Stanów Zjednoczonych w unipolarnym świecie, w przeciwieństwie do Unii Euroazjatyckiej, która dążyć będzie do stworzenia multipolarnego porządku globalnego. Unipolarne wyobrażenia USA koncentrują się przede wszystkim na własnym kraju, podczas gdy multipolarny porządek światowy uwzględnia „także” istotną rolę USA. W ramach takiego ładu, Stany Zjednoczone i jej sojusznicy będą w znacznej mierze uwolnieni od ponoszenia globalnej odpowiedzialności i ryzyka geopolitycznego, ekonomicznego i instytucjonalnego ${ }^{3}$.

3 Na początku prezydentury W. Putina priorytety rosyjskiej polityki zagranicznej przedstawiały się następująco: kraje Wspólnoty Niepodległych Państw, państwa Europy Zachodniej (głównie: Niemcy, Francja i Wielka Brytania), USA jako partner w sferze kontroli zbrojeń oraz kraje azjatyckie (głównie: ChRL, Indie i Japonia). Por.: S. Bieleń (2000), Orientacje ideowo-programowe w rosyjskiej polityce zagranicznej, „Stosunki Międzynarodowe”, nr 3-4. 
Takie postrzeganie roli Rosji na arenie międzynarodowej oznacza, iż region Morza Bałtyckiego nie należy do priorytetów rosyjskiej polityki zagranicznej. W wymiarze europejskim region ten pełni jednak ważną rolę, głównie ze względów geopolitycznych, ale także ekonomicznych i militarnych (Chełminiak, 2009: 120-121). Z tego względu Obwód Kaliningradzki pełni ważną rolę w rosyjskiej polityce bezpieczeństwa. Wynika to z jego położenia geograficznego, jako najbardziej na zachód wysuniętego obszaru Rosji, który graniczy z państwami NATO i UE oraz jedynego nie zamarzającego portu na Bałtyku (Rogoża i in., 2012: 12).

Rozpad ZSRR spowodował przekształcenie Bałtyckiego Okręgu Wojskowego (w skład, którego wchodził obszar Estonii, Łotwy, Litwy i Obwodu Kaliningradzkiego) w Północno-Zachodnią Grupę Wojsk, obecnie jest to Zachodni Okręg Wojskowy. Obwód Kaliningradzki wchodzi także w skład Bałtyckiej Strefy Morskiej, której głównym zadaniem jest zachowanie i umocnienie strategicznej pozycji militarnej w basenie Morza Bałtyckiego. Celowi temu służy m.in. rozbudowana infrastruktura wojskowa (system baz morskich, lotniczych (Czkałowsk, Czerniachowsk i Prawdinsk), obrony 140 km wybrzeża, zabezpieczenia magazynowo-technicznego itp.), która ma zapewnić ciagłość działań rosyjskim siłom zbrojnym w tej części Europy. Centralną funkcję w tym systemie pełni stacjonująca na obszarze obwodu Flota Bałtycka z głównymi bazami w Bałtijsku, Primorsku i Kaliningradzie. Jednostki marynarki wojennej i innych sił zbrojnych stacjonujące w obwodzie podlegają bezpośrednio resortom federalnym, które swych decyzji z reguły nie konsultują z władzami regionalnymi. Pomimo istotnej redukcji wojsk w obwodzie, pozostaje on nadal jednym z największych skupisk jednostek wojskowych w Rosji, stanowiących istotny element rosyjskiego potencjału wojennego. Znaczenie czynnika wojskowego w funkcjonowaniu obwodu jest tu większe niż w innych regionach FR, głównie z uwagi na oddalenie od reszty kraju oraz niewielką przestrzeń i zaludnienie. Zgromadzony potencjał wojskowy znacznie przewyższa potrzeby obronne regionu ${ }^{4}$.

W czasach ZSRR na terenie obwodu wybudowano system stacjonarnych wyrzutni rakiet średniego i dalekiego zasięgu uzbrojonych w głowice jądrowe. Miały one zapewniać wsparcie dla zajmowania cieśnin duńskich i opanowania wybrzeża Morza Północnego. Mogą być one w stosunkowo krótkim czasie ponownie wykorzystane do celów wojskowych (Szynowski, 2004: 5-6). Ważną rolę w obwodzie odgrywa zintegrowany system obrony powietrznej. W ramach modernizacji rosyjskich sił zbrojnych planowane jest rozmieszczenie w obwodzie systemu rakietowego ziemia-powietrze S-400 oraz rozmieszczenie wyrzutni rakiet Iskander. Charakteryzuje je bardzo duża mobilność, są one instalowane na podwoziach kołowych. Można je przewozić droga morską lub powietrzną, co oznacza, że w obwodzie mogą się znaleźć w krótkim okresie

4 Według różnych danych w obwodzie stacjonuje około 15-16 tys. żołnierzy, a wraz z innymi służbami mundurowymi około 25 tys. wobec około 140 tys. na początku lat 90-tych. Szacowano, że 10-30\% mieszkańców obwodu stanowili wojskowi i ich rodziny, a połowa terytorium i 30-40\% gospodarki obwodu związane było z wojskiem, co oznaczało uzależnienie od finansowania z budżetu centralnego. Por.: T. Palmowski (2013), Kaliningrad-szansa czy zagrożenie dla Europy Bałtyckiej? Monografia społeczno-gospodarcza, Gdańsk, s. 237. 
czasu. Ich zasięg wynosi około $500 \mathrm{~km}$. Także samoloty (SU-24) oraz okręty stacjonujące $\mathrm{w}$ obwodzie mogą przenosić głowice nuklearne ${ }^{5}$.

Specyficzne położenie geopolityczne obwodu jest wykorzystywane w sposób instrumentalny przez władze Federacji Rosyjskiej. Uzewnętrznia się to szczególnie jako karta przetargowa wobec USA, państw NATO w tym Polski oraz do wywierania presji na partnerów zagranicznych.

Było to szczególnie widoczne w przypadku Polski w latach 2008-2010, kiedy zawarto umowę z USA w sprawie projektu budowy tzw. tarczy antyrakietowej w Radzikowie pod Słupskiem. Po raz pierwszy strona rosyjska w lutym 2009 r. w ramach retorsji zagroziła, iż zainstaluje baterie rakiet Iskander (Radziwinowicz, 2009: 14). Kolejnym problemem okazało się przybycie w maju 2010 r. do Moraga (województwo warmińsko-mazurskie) grupy 33 amerykańskich żołnierzy z Bazy w Kaiserslauten w Niemczech, którzy obsługiwać mieli rotacyjnie baterię rakiet Patriot. Wraz z nimi przybyło 12 samochodów ciężarowych i dodatkowy personel. Ogółem cała grupa składała się ze stu osób. Liczący 15 tys. Morag leży około $70 \mathrm{~km}$ od granicy z Obwodem i $90 \mathrm{~km}$ od Kaliningradu. Zdaniem rosyjskiego MSZ nie sprzyjało to umacnianiu bezpieczeństwa i rozwojowi zaufania w Europie. $Z$ tego względu, tzn. by nie drażnić władz Rosji, Amerykanie wycofali się z Moraga (Ciechoński, 2010: 1; Podolski, 2011: 5). W sierpniu $2011 \mathrm{r}$. w prasie rosyjskiej i polskiej pojawiły się informacje, iż w nadbałtyckiej enklawie przy granicy z Polską władze Rosji zamierzają rozmieścić najnowocześniejsze rakiety przeciwlotnicze $S$-400 mogące razić cele oddalone o $400 \mathrm{~km}$ od wyrzutni. Zdaniem rosyjskich generałów broń ta ma być fundamentem obrony przeciwrakietowej, bo może także niszczyć rakiety z głowicami jądrowymi. Informacje te okazały się nieprawdziwe, gdyż rakiety $S$ - 400 znajdują się dopiero w fazie prób (Radziwinowicz, 2011: 11).

Kolejnym problemem związanym z Obwodem Kaliningradzkim, a wzbudzającym zaniepokojenie w Polsce były rosyjsko-białoruskie ćwiczenia wojskowe Zapad 2009 i Zapad 2013, które odbywały się także na terenie enklawy. Celem tych pierwszych było odpieranie ataku ze strony Polski, czyli NATO, co ożywiło stare lęki, które latami konserwowały sojusz. Celem manewrów Zapad 2013 było ćwiczenie procedur przerzutu rakiet Iskander, m.in. do Obwodu Kaliningradzkiego. Ćwiczenia te były zapowiedzią wymiany starych pocisków Toczka $V$ na nowe rakiety Iskander. Odbyły się one od 20 do 26 września 2013 r. Potencjalnym przeciwnikiem były państwa NATO, czyli w praktyce Regionalne Zgrupowanie Wojsk NATO, tj. Estonia, Łotwa, Litwa i Polska, jako państwa graniczne NATO. Ćwiczenia te stanowiły element szerszego programu szkolenia armii w Zachodnim Okręgu Wojskowym FR w ramach Połączonego Dowództwa Strategicznego „Zachód” (Wilk, 2013b).

2-9 listopada 2013 r. z inicjatywy Polski oraz Litwy, Łotwy i Estonii odbyły się na terytorium tych państw ćwiczenia NATO pod nazwą Steadfast Jazz 2013. Celem manewrów było m.in. ćwiczenie wariantu udzielenia Estonii wsparcia militarnego w obli-

5 W grudniu 2011 r. w obwodzie oddano do eksploatacji nowoczesną stację radiolokacyjną sytemu wczesnego ostrzegania o ataku rakietowym Woroneż - DM. Patrz: J. Rogoża, A. Wierzbowska-Miazga, I. Wiśniewska (2012), Wyspa na uwięzi. Kaliningrad między Moskwq a UE, Warszawa, s. 13 . 
czu zagrożenia. Zdaniem Rosjan ćwiczenia były wymierzone przeciw ich interesom, gdyż w regionie tym nie ma innego przeciwnika dysponującego możliwością ataku (Ćwieluch, 2013: 16-18). Paweł Wroński komentując zapowiadane manewry NATO zauważył, iż: „Polska i rosyjska opinia publiczna od lat są przeświadczone, że oba państwa sobie zagrażają. Z punktu widzenia Rosji Polska wzmacnia antyrosyjskie oblicze NATO, a przez budowę tarczy antyrakietowej chce uczynić ostatni militarny argument Rosji - broń jądrową - nieużytecznym.

W Polsce nienawiść do Rosji jest dla części klasy politycznej wyznacznikiem patriotyzmu. Przy okazji przeprowadzanych co dwa lata rosyjskich manewrów Zapad słyszymy od nich, jak to niby rosyjskie władze przygotowują się do stłumienia wraz z Białorusią polskiego powstania w Grodnie i przeprowadzenia jądrowego ataku na Warszawę. Każda współpraca z Rosjąjest przez tych polityków traktowana jak zdrada. [...] W tym roku jednym z największych sukcesów polskiej dyplomacji było doprowadzenie do odwołania przewidzianych na lato tego roku ćwiczeń wojsk pancernych Niemiec i Rosji. Miały wspólnie zwalczać atak terrorystyczny. Według tygodnika „Der Spiegel" polska dyplomacja wskazywała na to, że ta współpraca wojskowa jakoś tak przypomina współpracę z czasów Ribbentropa i Mołotowa. Ćwiczenia zostały przełożone i mają się odbyć ,może za rok, może za dwa”. Chyba czas już najwyższy, aby to Polska wystapiła z inicjatywą wspólnych niemiecko-rosyjsko-polskich manewrów. Mogłyby odbyć się na poligonie w Drawsku, gdzie w przeszłości ćwiczyły przecież wojska i rosyjskie, i niemieckie, albo w Żaganiu, w końcu była to kiedyś radziecka baza. Może to najlepszy sposób, by odpędzać demony przeszłości. Być może po takich ćwiczeniach Polska, ale też Rosja poczują się bezpieczniej” (Wroński, 2013b: 5).

Fiasko rozmów Rosja-NATO na temat instalacji amerykańskiej ,tarczy antyrakietowej" w Europie spowodowało reakcję Rosji. 25 stycznia 2012 r. agencja Interfax, powołując się na źródło w Kaliningradzkim Sztabie Floty Bałtyckiej, poinformowała o rozpoczęciu przygotowań do rozmieszczenia w obwodzie rakiet balistycznych krótkiego zasięgu 9K720 Iskander. Tego samego dnia informacja ta została zdementowana przez Sztab Generalny Sił Zbrojnych FR w Moskwie. Następnego dnia Ministerstwo Obrony Litwy wyraziło negatywne stanowisko w tej sprawie. Władze Rosji po raz kolejny użyły wobec Polski i NATO jako argumentu rakiet Iskander. Zdaniem Andrzeja Wilka, strona rosyjska od początku traktuje sprawę instrumentalnie i „konsekwentnie stara się przedstawiać swoje działania jako krok odwetowy w odpowiedzi na działania amerykańskie. Tymczasem przezbrojenie jednostek armii rosyjskiej w Obwodzie Kaliningradzkim wynika z ogólnych założeń modernizacji technicznej armii rosyjskiej” (Wilk, 2012).

W 2013 r. Stany Zjednoczone potwierdziły decyzję o zawieszeniu budowy IV fazy tarczy antyrakietowej, która przewidywała instalację w Polsce antyrakiet SM-3. Podczas cyklicznego spotkania Trójkąta Kaliningradzkiego (nazywanego przez polskie MSZ Trójkątem Królewieckim) 10 maja 2013 r. w Warszawie, w którym uczestniczyli szefowie MSZ Polski, Niemiec i Rosji, minister Siergiej Ławrow - jak stwierdził Radosław Sikorski - ,powtórzył stanowisko prezydenta Miedwiediewa, że jeśli w Polsce nie będzie IV fazy tarczy, to znaczy nieistniejących jeszcze typów amerykańskich antyrakiet, to Rosjanie nie rozmieszczą w okręgu królewieckim pocisków średniego zasięgu typu Iskander: Trzymamy za słowo". Minister R. Sikorski zauważył także, że: 
„Mamy solenną obietnicę administracji amerykańskiej, że baza tarczy antyrakietowej w Radzikowie pod Słupskiem powstanie w wersji, która obroni Europę, ale nie wpłynie na międzykontynentalny potencjał rosyjski. Jesteśmy realistami i nadal uważamy, że USA w sprawie tarczy antyrakietowej będą się kierować swoją oceną sytuacji międzynarodowej i wielkością budżetu obronnego. Gdyby jednak te zapowiedzi się spełniły, to nie byłoby źle, bo mielibyśmy w Polsce dwie amerykańskie bazy. Do bazy w Łasku przylatują już amerykańskie myśliwce $F-16$, których załogi ćwiczą z Polakami. To efekt tego, że w przeciwieństwie do poprzedniego rządu podczas negocjacji o tarczy stawialiśmy warunki. Rząd PiS, podobnie jak Czech, był gotów wziąć w ciemno to, co Amerykanie dawali. Czesi w efekcie nie mają ani radaru, który miał być elementem tarczy, ani nic w zamian" (Nic w Polsce, 2013: 18) ${ }^{6}$.

Po raz kolejny „,iskanderowy straszak” pojawił się w końcu 2013 r. 14 grudnia na łamach czasopisma „Bild” ukazał się artykuł o rozmieszczeniu w 2013 r. wzdłuż granicy obwodu z Polską i Litwą rakiet Iskander (kod NATO SS-26 Stone). W zasięgu tych rakiet balistycznych średniego zasięgu mogących przenosić głowice jądrowe, znajduje się nie tylko całe terytorium Polski i Litwy, ale także Berlin. Ich rozmieszczenie, zdaniem gazety, ma stanowić odpowiedź na budowę „tarczy antyrakietowej”. Głos w tej sprawie zabrał prezydent W. Putin, który 19 grudnia 2013 r. stwierdził, że w Obwodzie Kaliningradzkim nie ma rakiet Iskander. W tym kontekście pojawiły się ponownie spekulacje na temat taktycznej broni jądrowej, która prawdopodobnie znajduje się w obwodzie od czasów sowieckich ${ }^{7}$.

$\mathrm{Na}$ pytanie dziennikarza, czy sprawa rakiet Iskander w obwodzie może mieć związek z polską decyzją o rozmieszczeniu na granicy z obwodem dwóch baterii haubicoarmat Krab, w których zasięgu (40 km) jest duża część obwodu, w tym Kaliningrad i są trudne do lokalizacji, generał Stanisław Koziej, szef Biura Bezpieczeństwa Narodowego stwierdził wymijająco, iż: „W przypadku wojny granice przestają istnieć i dyskusja o zasięgach danej broni traci sens. Zwykle zresztą planiści, szczególnie gdy planują operację obronna, a nie ofensywna, starają się trzymać najcenniejsze elementy uzbrojenia z dala od granic, poza zasięgiem agresora mogącego zawsze wykonać uderzenie z zaskoczenia" (Iskandery na postrach, 2013: 6). W sprawie rozmieszczenia rakiet Iskander zauważył, iż jest to element wojny propagandowej, gdyż: „Można

${ }^{6}$ Poprzednie spotkania szefów dyplomacji w ramach Trójkąta Kaliningradzkiego odbyły się w maju 2011 r. w Kaliningradzie i w marcu 2012 r. w Berlinie. Kolejne spotkanie planowane jest w 2014 r. w Sankt Petersburgu. Celem tych regularnych konsultacji jest zacieśnianie regionalnej współpracy i przegląd aktualnych zagadnień politycznych.

W. Putin na konferencji prasowej zauważył: „takiej decyzji nie podjęliśmy. Nie ma powodu do niepokoju". Patrz: Wtadimir Putin dementuje doniesienia o Iskanderach w Kaliningradzie, PAP, 19.12.2013, http;//konflikty.wp.pl (2014). Por. także: P. Wroński (2013), Miłosierdzie Rosji, „Gazeta Wyborcza", 20.12.2013. 16 grudnia 2013 r. rzecznik ministerstwa obrony Rosji stwierdzil, że Iskandery znajdują się na wyposażeniu Zachodniego Okręgu Wojskowego, a ich rejony dyslokacji nie naruszają porozumień międzynarodowych. Najprawdopodobniej w najbliższym czasie w ramach planowej modernizacji armii 152. Brygada Rakietowa stacjonująca w Czerniachowsku w Obwodzie Kaliningradzkim zostanie przezbrojona w rakiety Iskander. Pierwsze egzemplarze najprawdopodobniej trafiły do obwodu w 2013 r. w ramach wrześniowych ćwiczeń z 26 Brygadą Rakietowej z Ługi, Obwód Leningradzki (obie jednostki należą do Zachodniego Okręgu Wojskowego) i pozostały w Czerniachowsku. 
dyskutować, czy Berlin jest w zasięgu Iskanderów, ale przecież bezdyskusyjne jest, że znajduje się w zasięgu innych rosyjskich rakiet. [...] to nieistotne, czy te rakiety są na Uralu, pod Petersburgiem czy przy granicy z Polską, w każdej chwili można je przewieźć tam, gdzie będą w danym czasie potrzebne" (ibidem).

Zdaniem ekspertów ewentualne stacjonowanie czy rozmieszczenie broni jądrowej w Obwodzie Kaliningradzkim ma - jak zauważa Marcin Chełminiak - „drugorzędne znaczenie dla bezpieczeństwa Polski, Litwy oraz pozostałych państw regionu. Nie zmieniłoby to sytuacji militarnej nad Bałtykiem, ponieważ Rosja posiada inne możliwości dokonania uderzenia jądrowego (m.in. za pomocą wyrzutni rakiet strategicznych stacjonujących na okrętach podwodnych oraz w głębi FR)" (Chełminiak, 2009: 132).

Stacjonowanie rakiet $\mathrm{z}$ głowicami jądrowymi ma przede wszystkim znaczenie obronne i psychologiczno-polityczne. Po dokonaniu radykalnej redukcji wojsk w obwodzie (do 15 tys.) nie są one w stanie prowadzić istotnych działań ofensywnych (może w przypadku osamotnionej Litwy). Nie dziwi zatem fakt, że władze Rosji w zaistniałej sytuacji, postanowiły przede wszystkim skoncentrować się na odstraszaniu za pomocą 152 Brygady Rakiet Taktycznych w Czerniachowsku (wyposażonej w 12 wyrzutni Toczka a w przyszłości w ramach modernizacji w Isandery) oraz rozbudowanej obrony przeciwlotniczej (rakiety $S$-300, w przyszłości $S-400$ w dwóch jednostkach: 183. Pułku w Gwardijsku i na Mierzei Wiślanej oraz rakiety Tor w 22. Pułku w Kaliningradzie). Rosjanie zakładają, że przy takiej sile ognia, każdy się wielokrotnie zastanowi nim podejmie decyzję o uderzeniu z lądu, morza lub powietrza. Jeszcze na przełomie XX i XXI wieku rosyjscy stratedzy zakładali, iż wojska stacjonujące w obwodzie będą zdolne zająć Gdańsk, Gdynię i Sopot w ciągu 90 minut, a w ciagu 12 godzin dotrzeć na przedmieścia Warszawy. W ciągu następnych 12 godzin gotowe są rozwinąc natarcie w kierunku Poznania i Wrocławia. W przypadku konfliktu z państwami bałtyckimi na rozpoczęcie natarcia siły rosyjskie potrzebowałyby kilkudziesięciu minut (Wojnowski, 2002: 441-453; Drzewiecki, 2001: 70-78).

O tym, że Obwód Kaliningradzki może stać się realnym powodem do napięć w polityce międzynarodowej, świadczy spór pomiędzy Litwą i Rosją z października 2013 r. Litwa w tym czasie przewodziła radzie UE, a w listopadzie miała być gospodarzem szczytu Partnerstwa Wschodniego. Władze Ukrainy ostatecznie wycofały się z podpisania umowy stowarzyszeniowej z UE w Wilnie, a przedstawiciele Armenii ogłosili we wrześniu 2013 r., że Armenia przystąpi do Unii celnej tworzonej przez Rosję, Białoruś i Kazachstan. Władze Rosji postanowiły wywrzeć presję na Litwę, rozpoczynając 20 września 2013 r. stosowanie wobec litewskich przewoźników nowych restrykcji. Tym samym zmuszono ich do transportowania ładunków od granicy litewsko-rosyjskiej do urzędu celnego pod eskortą. Wcześniej przez ponad tydzień strona rosyjska prowadziła też dodatkowe kontrole celne rosyjskich towarów. Kreml nie wyjaśniał motywów tych działań. Spytany o ewentualne działania odwetowe, minister spraw zagranicznych Litwy Linas Linkeviczius powiedział agencji Reuters, że Litwa „również mogłaby zastosować takie same środki. Obwód Kaliningradzki jest geograficznie odizolowanym regionem, więc [...], możemy na przykład odciąć transport" - dodał.

8 Podobną opinię wyraził Adam Daniel Rotfeld były minister spraw zagranicznych RP w wywiadzie pt. Putin pokazuje poddanym wielkoduszność, „Gazeta Wyborcza”, 21-22.12.2013, s. 9. 
„Moglibyśmy odciąć połączenie kolejowe, ale nie tylko, również dostawy towarów. Teoretycznie jest to możliwe. Ta kwestia nie była omawiana, to nie jest nasz sposób myślenia, to nie są nasze metody" - sprecyzował. Na pytanie o możliwych działaniach odwetowych Rosji odparł, że ,możliwe jest odcięcie gazu. - Oni [Rosjanie] są bardzo konkretni",9.

Znaczenie Obwodu Kaliningradzkiego dla bezpieczeństwa Polski jest uzależnione od stanu ogólnych stosunków polsko-rosyjskich i relacji między FR a NATO i UE. Ten najbardziej na zachód wysunięty obszar Rosji stanowić może jednak potencjalne zagrożenie dla bezpieczeństwa Polski i państw regionu Morza Bałtyckiego.

\section{Bibliografia}

Bieleń S. (2000), Orientacje ideowo-programowe w rosyjskiej polityce zagranicznej, „Stosunki Międzynarodowe", nr 3-4.

Briukow S., Sawin W. (2013), Russland-Wiederaufstieg einer Macht?, w: Hegemonie und Multipolarität. Weltordnungen im 21. Jahrhundert, (Hrsg.) E. Crome, R. Kramer, Potsdam.

Buzan B. (2012), Dezentrierter Globalismus. Weltordnung ohne Supermachte, „WeltTrends”, nr 86.

Chełminiak M. (2009), Obwód Kaliningradzki FR w Europie. Rosyjska enklawa w nowym międzynarodowym ładzie politycznym, Torun.

Ciechoński T. (2010), Morag (chyba) żegna Patrioty. Nie chcq drażnić Rosji, „Gazeta Wyborcza. Olsztyn", 12.10.2010.

Ćwieluch J. (2013), Jazz na poligonie. Obserwujac przygotowania do manewrów Steadfast Jazz, trudno się dziwić, że prezydent Bronisław Komorowski zabiega o to, by w razie czego Polska bronita się sama, „Polityka”, nr 45.

Drzewiecki A. (2011), Obwód Kaliningradzki w polityce bezpieczeństwa Polski i Litwy w kontekście rozszerzenia NATO i Unii Europejskiej na Wschód, w: Kraje Europy Środkowej i Wschodniej wobec procesu integracji europejskiej, (red.) J. Albin, J. Kupczak, Wrocław.

Działania militarne w Prusach Wschodnich (1998), (red.) W. Wróblewski, Warszawa.

Iskandery na postrach Polakom (2013), Rozmowa z gen. Stanisławem Koziejem, „Gazeta Wyborcza", 18.12.2013.

Jendroszczyk P. (1998), Nowa broń w Kaliningradzie, „Rzeczpospolita”, 12.06.1998.

Nic w Polsce bez Polski (2013), Rozmowa z ministrem spraw zagranicznych Radosławem Sikorskim, „Gazeta Wyborcza”, 18-19.05.2013.

Palmowski T. (2013), Kaliningrad - szansa czy zagrożenie dla Europy Battyckiej? Monografia społeczno-gospodarcza, Gdańsk.

Panarin A. S. (1999), Rosja w cikłach mirowoj istorii, Moskwa.

Podolski M. (2011), US Army nie trafito w Morag, „Gazeta Wyborcza”, 24-25.09.2011.

Politkowska A. (2007), Imperium Putina, Warszawa.

Politkowska A. (2005), Rosja Putina, Warszawa.

9 Po opublikowaniu tego materiału wywiązała się internetowa debata. Jeden z jej uczestników zauważył, iż: „Obwód Kaliningradzki jest obszarem bezprawnie zajętym przez Rosję. Tam zacznie się trzecia wojna światowa w Europie" (ibidem, 5.01.2014). 
Putin pokazuje poddanym wielkoduszność (2013), Rozmowa z Adamem Danielem Rotfeldem, byłym ministrem spraw zagranicznych RP, „Gazeta Wyborcza”, 21-22.12.2013.

Radziwinowicz W. (2009), Iskandery w Kaliningradzie?, „Gazeta Wyborcza”, 12.02. 2009.

Radziwinowicz W. (2011), Rosja straszy wirtualnymi rakietami, „Gazeta Wyborcza”, 10.08.2011.

Rogoża J., Wierzbowska-Miazga A., Wiśniewska I. (2012), Wyspa na uwięzi. Kaliningrad między Moskwq a UE, Warszawa.

Sakson A. (1994a), Kaliningrad und Europa Sicherheit. Ein polnischer Standpunkt, „WeltTrends”, nr 2.

Sakson A. (2011a), Geostrategiczne aspekty „,problemu kaliningradzkiego”, „Przegląd Strategiczny", nr 2 .

Sakson A. (2011b), Od Kłajpedy do Olsztyna. Wspótcześni mieszkańcy byłych Prus Wschodnich: Kraj Kłajpedzki, Obwód Kaliningradzki, Warmia i Mazury, Olsztyn.

Sakson A. (1994b), Problem teraźniejszości i przyszłości Okręgu Kaliningradzkiego (Królewca) w polityce europejskiej, „Europa”, nr 1.

Sakson A. (1993), Teraźniejszość i przyszłość Obwodu Kaliningradzkiego. Aspekty polityczne i kwestie bezpieczeństwa międzynarodowego, „Przegląd Zachodni”, $\mathrm{nr} 3$.

Sakson A. (1994c), Teraźniejszość i przyszłość Obwodu Kaliningradzkiego (Królewca), „Przegląd Zachodni", nr 3.

Sakson A. (1994d), The Problem of the Kaliningrad Region, „Polish Western Affairs”, No. 1.

Sakson A. (2012), Varmijos ir Mazurijos prijungimas prie Lenkijos. Legitimavimo prielajdos ir praktikos, „Acta Historica Universitatis Klaipedensis”, Vol. XXIV.

Schütz N., Gruber E. (2000), Mythos Reichsautobahn. Bau und Inszenierung der ,, Straßen des Führers" 1933-1941, Berlin.

Szynowski R. (2004), Obwód Kaliningradzki na politycznej, gospodarczej i militarnej mapie Europy na przełomie XX i XXI w., „Przegląd Morski”, nr 1.

Szymański M. (1999), Potencjał militarny w Obwodzie Kaliningradzkim a bezpieczeństwo Polski, „Przegląd Zachodni”, nr 1.

Teheran-Jałta-Poczdam. Dokumenty konferencji szefów trzech wielkich mocarstw (1972), Warszawa.

Wilk A. (2013a), Iskandery na granicach NATO, „Analizy Ośrodka Studiów Wschodnich”, 18.12.2013.

Wilk A. (2012), Iskandery w Obwodzie Kaliningradzkim niezależne od „tarczy antyrakietowej”, „Analizy Ośrodka Studiów Wschodnich".

Wilk A. (2013b), „Zachód 2013” - ćwiczenia z antynatowskiej integracji armii białoruskiej i rosyjskiej „Analizy Ośrodka Studiów Wschodnich”.

Winiecki J. (2012), Moskwa przyciaga. W kolejnych republikach dawnego ZSRR dochodza do władzy prorosyjscy politycy. Poczatek odbudowy imperium? Raczej powrót do normalności, „Polityka”, $\mathrm{nr} 44$.

Wojnowski E. (2002), Unia Europejska wobec Obwodu Kaliningradzkiego, „Komunikaty Warmińsko-Mazurskie", nr 3.

Wroński P. (2013a), Miłosierdzie Rosji, „Gazeta Wyborcza”, 20.12.2013.

Wroński P. (2013b), NATO ćwiczy w Polsce, kiedy dołaczy Rosja, „Gazeta Wyborcza”, 2-3.11.2013.

Wrzesiński W. (1994), Prusy Wschodnie w polskiej myśli politycznej w latach 1864-1945, Olsztyn. 


\title{
STRESZCZENIE
}

Obwód Kaliningradzki Federacji Rosyjskiej (FR) odgrywa istotną rolę dla bezpieczeństwa Polski, Litwy oraz państw regionu Morza Bałtyckiego. Ten najbardziej na zachód wysunięty obszar Rosji otoczony jest państwami UE i NATO i nie posiada bezpośredniej styczności z FR. Na obszarze obwodu zgromadzone są pokaźne siły zbrojne, w tym wyrzutnie rakiet średniego i dalekiego zasięgu, które mogą być uzbrojone w głowice atomowe. Władze w Moskwie traktują potencjał wojskowy zgromadzony w obwodzie jako element nacisku na opinię publiczną, tak by zniechęcić władze RP do budowy na terytorium Polski amerykańskiej tarczy antyrakietowej.

\section{THE KALININGRAD OBLAST AND POLAND'S SECURITY}

\begin{abstract}
The Kaliningrad Oblast of the Russian Federation (RF) is significant for the security of Poland, Lithuania and the Baltic countries. This westernmost region of Russia is surrounded by EU and NATO states and does not have a direct contact with the RF. Considerable military potential is concentrated in this region, including medium and long range missile launchers that may be armed with nuclear warheads. The government in Moscow treats the military potential of this region as an element of pressure to influence public opinion and discourage the Polish authorities from building the US anti-missile system in Poland.
\end{abstract}


